\title{
Toxicity of representative mixture of five rare earth elements in juvenile rainbow trout (Oncorhynchus mykiss) juveniles
}

\author{
Houda Hanana ${ }^{1} \cdot$ Christine Kleinert $^{1} \cdot$ François Gagné ${ }^{1}$ \\ Received: 28 July 2020 / Accepted: 22 December 2020 / Published online: 3 February 2021 \\ (C) Crown 2021
}

\begin{abstract}
Rare earth elements (REEs) are contaminants of increasing interest due to intense mining activities for commercial purposes and ultimately released in the environment. We exposed juvenile rainbow trout (Oncorhynchus mykiss) to a representative mixture of the five most abundant REEs for $96 \mathrm{~h}$ at concentrations similar found in lakes contaminated by mining activities at $0.1,1,10$, and 100X whereas the 1x mixture contained cerium (Ce, $280 \mu \mathrm{g} / \mathrm{L})$, lanthanum ( $\mathrm{La}, 140 \mu \mathrm{g} / \mathrm{L})$, neodymium $(\mathrm{Nd}, 120 \mu \mathrm{g} / \mathrm{L})$, praseodymium ( $\mathrm{Pr}, 28 \mu \mathrm{g} / \mathrm{L}$ ), and samarium $(\mathrm{Sm}, 23 \mu \mathrm{g} / \mathrm{L}$ ). We investigated the expression of 14 genes involved in oxidative stress, DNA repair, tissue growth/proliferation, protein chaperoning, xenobiotic biotransformation, and ammonia metabolism in the liver. In addition, DNA damage, oxidative stress (lipid peroxidation or LPO), inflammation (cyclooxygenase or COX activity), detoxification mechanisms (glutathione-S-transferase activity or GST), and labile zinc were determined in gills. The data revealed that genes involved in oxidative stress-catalase ( $c a t)$, heat shock proteins 70 ( $h s p 70$ ), and glutamate dehydrogenase $(g l u d)$ were upregulated while glutathione S-transferase $(g s t)$ and metallothionein $(m t)$ gene expressions were downregulated. The mixture was genotoxic and increased labile $\mathrm{Zn}$ in gills of exposed trout. These changes occurred at concentrations 600 times lower than the $\mathrm{LC}_{50}$ for this mixture indicating effects below the $1 \mathrm{X}$ concentration. Based on principal component analysis and concentration-dependent reponses, the following sublethal effects were considered the most important/significant: DNA strand breaks (genotoxicity), labile Zn, cat, gst, hsp70, sparc, mt, and glud. These effects of fish juveniles are likely to occur in environments under the influence of mining activities.
\end{abstract}

Keywords Rare earth elements · Mixtures · Oxidative stress · Toxicity

\section{Introduction}

Rare earth elements (REEs) comprise the 15 elements of the lanthanide family in addition to scandium and yttrium. Demand for these chemicals is increasing, as they are essential for a number of technological products including smartphones and miscellaneous computer parts. As recycling rates of REEs are below $1 \%$ (Binnemans et al. 2013), mining efforts have to be increased to meet demand and suggests that REEs could find their way in the environment.

Responsible Editor: Philippe Garrigues

François Gagné

francois.gagne@canada.ca

1 Aquatic Contaminants Research Division, Environnement and Climate Change Canada, 105 McGill, Montréal, QC H2Y 2E7, Canada
REEs are considered contaminants of emerging interest, as mining efforts and subsequent release into the aquatic environment raise concerns about the ecotoxicological impacts to the aquatic environment. This group of chemicals has already been detected in the marine (Moermond et al. 2001), freshwater (Kulaksiz and Bau 2011), and soil environment (Tranchida et al. 2011) as well as biota (Tu et al. 1994; Bustamante and Miramand 2005; Hu et al. 2006; Censi et al. 2013; Fu et al. 2014; Mayfield and Fairbrother 2015). However, information on potential adverse toxicological effects and toxicity mechanisms is still scarce to date for this group of elements.

The toxicological investigations of a number of REEs have been studied in fish and aquatic invertebrates. Lanthanum $\left(\mathrm{La}^{3+}\right)$ and Cerium $\left(\mathrm{Ce}^{3+}\right)$ are the most frequently studied REEs owing to their abundance and use. Zebra fish (Danio rerio) embryo and larval development were delayed; survival and hatching rates were decreased and tail malformations occurred after La exposure (Cui et al. 2012). Lanthanum chloride $\left(\mathrm{LaCl}_{3}\right)$ has been shown to affect acetylcholinesterase 
kinetics in electric eel (Electrophorus electricus) (Tomlinson et al. 1982) as well as electroreceptor sensitivity in catfish (Kryptopterus sp.) (Roth 1982). Furthermore, growth arrest DNA repair gene (gadd45) expression was increased 2-fold relative to controls after $96 \mathrm{~h}$ exposure to La in juvenile rainbow trout (Oncorhynchus mykiss) (Dubé et al. 2019). This acute lethality assay in juvenile rainbow trout is a standardized bioassay and currently used to regulate the toxicity of wastewaters under the Canadian Environmental Protection Act. In aquatic invertebrates, a variety of biochemical processes have been shown to be affected by La exposure including but not limited to lipid peroxidation (LPO), gluthathione-Stransferase (GST) activity, and citrate synthase (Hanana et al. 2017). Furthermore, La has displayed embryotoxicity in several sea urchin species (Trifuoggi et al. 2017).

Cerium $(\mathrm{Ce})$ was frequently tested in its nanoparticle form. Cerium oxide nanoparticles $\left(\mathrm{nCeO}_{2}\right)$ showed elevated plasma cortisol levels in white sucker (Catostomus commersonii) after acute in vivo exposure to $1 \mathrm{mg} / \mathrm{L} \mathrm{nCeO}_{2}$ for $25 \mathrm{~h}$. Biomarkers for oxidative, cardiorespiratory, or osmoregulatory stress, however, remained unchanged, suggesting mild toxicity effects outside of the cardiorespiratory system (Rundle et al. 2016). Heat shock protein 70 (hsp 70) gene expression significantly increased after $96 \mathrm{~h}$ exposure to $\mathrm{Ce}^{3+}$ in juvenile rainbow trout (Dubé et al. 2019) indicating a stress response related to exposure. Furthermore, $\mathrm{Ce}^{3+}$ was tested for its antioxidant capacities in the liver of Silver crucian carp (Carassius gibelio) injected with lead $(\mathrm{Pb})$. It decreased reactive oxygen species (ROS) production and LPO while improving catalase, superoxide dismutase (SOD), and ascorbate peroxidase activities (Ling and Hong 2010). Ce effects in aquatic invertebrates include morphological changes at relatively low concentrations $\left(\mathrm{EC}_{50}=0.05 \mathrm{mg} / \mathrm{L}\right)$ and mortality $\left(\mathrm{LC}_{50}=0.33 \mathrm{mg} / \mathrm{L}\right)$ in Hydra attenuata after $96 \mathrm{~h}$ exposure (Blaise et al. 2018). Furthermore, Ce has displayed embryotoxicity in several sea urchin species (Trifuoggi et al. 2017). Neodymium (Nd) nanoparticles $\left(\mathrm{nNd}_{2} \mathrm{O}_{3}\right)$ affected heart rate, the cerebrovascular system, and neural apoptosis in zebra fish embryos (Chen et al. 2020). Furthermore, Nd exposure significantly increased hsp70 gene expression in rainbow trout (Dubé et al. 2019). $\mathrm{Nd}$ effects in aquatic invertebrates include induced morphological changes $\left(\mathrm{EC}_{50}=0.09 \mathrm{mg} / \mathrm{L}\right)$ and mortality $\left(\mathrm{LC}_{50}=\right.$ $0.31 \mathrm{mg} / \mathrm{L}$ ) in Hydra attenuata after $96 \mathrm{~h}$ exposure (Blaise et al. 2018). Moreover, Nd has displayed embryotoxicity in several sea urchin species (Trifuoggi et al. 2017). Samarium (Sm) significantly increased cyplal gene expression in rainbow trout (Dubé et al. 2019) indicating possible perturbation in phase I biotransformation of non-polar aromatic hydrocarbons. It was the second most toxic compound with Yttrium to juvenile rainbow trout in the above study. In aquatic invertebrates, $\mathrm{Sm}^{3+}$ has been shown to affect gene expression of GST, catalase (cat), cytochrome c oxidase 1 (COI), and cyclin $D$ (Hanana et al. 2018). Furthermore, both prostaglandin cyclooxygenase (COX) activity and DNA strand breaks were decreased (Hanana et al. 2018). In Hydra attenuata, Sm induced morphological changes $\left(\mathrm{EC}_{50}=0.18 \mathrm{mg} / \mathrm{L}\right)$ and mortality $\left(\mathrm{LC}_{50}=0.77 \mathrm{mg} / \mathrm{L}\right)$ after $96 \mathrm{~h}$ exposure (Blaise et al. 2018). Sm oxide nanoparticles $\left(\mathrm{nSm}_{2} \mathrm{O}_{3}\right)$ were also considered toxic in another study on Hydra (Blaise et al. 2008). Furthermore, Sm has displayed embryotoxicity in several sea urchin species (Trifuoggi et al. 2017). Finally, praseodymium $(\mathrm{Pr})$ effects in aquatic invertebrates include induced morphological changes $\left(\mathrm{EC}_{50}=0.02 \mathrm{mg} / \mathrm{L}\right)$ and mortality $\left(\mathrm{LC}_{50}=0.56 \mathrm{mg} / \mathrm{L}\right)$ in Hydra attenuata after $96 \mathrm{~h}$ exposure (Blaise et al. 2018).

The majority of the toxicological database comprises two of the elements: cerium (Ce) and lanthanum (La) but virtually no information exists about environmentally realistic mixtures. In our study, we wanted to investigate the effect of an environmentally relevant mixture of the first 5 most-abundant REEs ( $\mathrm{La}, \mathrm{Ce}, \mathrm{Nd}, \mathrm{Sm}$, and $\mathrm{Pr}$ ) based on reported values in lakes contaminated by mining activities in the North of Quebec (Canada) (Beaubien 2015). The first five most abundant REEs were prepared at different concentrations but keeping the same proportion between them and exposed to juvenile rainbow trout for toxicity investigations. Compared to natural lakes, these concentrations are $2-3$ orders of magnitudes higher and with similar relative ratios. We evaluated genotoxicity (DNA strand breaks), mRNA expression of a set of genes involved in oxidative stress, $\mathrm{Fe} 3+$ /divalent metal homeostatis, DNA repair, protein denaturation, cell growth/ proliferation and intermediary metabolism and biochemical markers of oxidative stress (lipid peroxidation), inflammation (cyclooxygenase activity), detoxification mechanisms (glutathione-S-transferase activity), and labile zinc, which is a biomarker for metal exposure, in the gills and liver.

\section{Material and methods}

\section{Exposure of rainbow trout to a mixture of selected REEs}

Rainbow trout juveniles (length: $7.7 \mathrm{~cm} \pm 0.2 \mathrm{~cm}$; weight: $4.2 \mathrm{~g} \pm 0.3 \mathrm{~g}$ ) were maintained for 2 weeks at $15{ }^{\circ} \mathrm{C}$ on a photoperiod of $16 \mathrm{~h}$ light/ $8 \mathrm{~h}$ dark and constant aeration, following a standardized protocol of Environment and Climate Change (Environmental Protection Series 1990). The aquarium water obtained from UV-treated, charcoalfiltered tap water from the city of Montreal (QC, Canada). Trout were used to determine the lethal and sublethal toxicity of a mixture of 5 REEs (lanthanum, cerium, neodymium, samarium, and praseodymium) after $96 \mathrm{~h}$ exposure to environmentally relevant concentrations $(1 \mathrm{x})$ and incremental concentrations ranging from $0.1 \mathrm{x}$ to $100 \mathrm{x}$ (Table 1 ). The toxicity was also examined with the REEs individually. The nominal 
Table 1 Concentrations of the individual lanthanides in the REE mixture. The $1 \mathrm{x}$ concentration is based on measured concentrations in a lake contaminated by mining activities (Beaubien 2015)

\begin{tabular}{llllll}
\hline Concentration $(\mu \mathrm{g} / \mathrm{L})$ & $\begin{array}{l}\text { Lanthanum } \\
\text { La }\end{array}$ & $\begin{array}{l}\text { Cerium } \\
\mathrm{Ce}\end{array}$ & $\begin{array}{l}\text { Neodymium } \\
\mathrm{Nd}\end{array}$ & $\begin{array}{l}\text { Samarium } \\
\text { Sm }\end{array}$ & $\begin{array}{l}\text { Praseodymium } \\
\mathrm{Pr}\end{array}$ \\
\hline $0.1 \mathrm{x}$ & 14 & 28 & 12 & 2.3 & 2.8 \\
$1 \mathrm{x}$ & 140 & 280 & 120 & 23 & 28 \\
$10 \mathrm{x}$ & 1400 & 2800 & 1200 & 230 & 280 \\
$100 \mathrm{x}$ & 14,000 & 28,000 & 12,000 & 2300 & 2800 \\
\hline
\end{tabular}

concentrations were selected based on the concentrations found in the aquatic environment contaminated by mining activities (Beaubien 2015).

For each lanthanide, stock solutions were prepared one day prior to exposure beginning by dissolving the chloride salts of each REE in distilled water. The final concentrations correspond to the amount of elemental ions in each solution. The stock solutions were further diluted to obtain the 100x REE mixture, which was then used to obtain the $0.1 \mathrm{x}, 1 \mathrm{x}$, and $10 \mathrm{x}$ dilutions. For each concentration, $1 \mathrm{~L}$ was prepared and added to a final volume of $60 \mathrm{~L}$ tap water (dechlorinated, UV-treated tap water from the city of Montreal). Then, the rainbow trout were placed in polyethylene bag-lined $60 \mathrm{~L}$ containers $(n=13$ fish per concentration). The trout in the negative control (NC) was exposed to tap water only. Physico-chemical parameters of the aquarium water were monitored daily. No difference in physico-chemical parameters was observed between different concentrations of the REE exposure mediums. Fish were additionally monitored daily for signs of distress, behavior changes, and mortality.

At the end of the exposure, the $96 \mathrm{~h}$ median lethal concentration that led to $50 \%$ mortality $\left(\mathrm{LC}_{50}\right)$ was determined with the Spearman-Karber method (Finney 1964) using CETIS software (version 1.8.7.7). Trout were euthanized with $0.1 \%$ MS222 (Sigma-Aldrich, Oakville, ON, Canada) according to the recommendations of the animal care committee. Fish exposed to 100x REE mixture were not used for further experiments due to the high mortality observed $(61.5 \%)$. The length and weight of each fish were recorded. Then, the gills and livers were immediately dissected. Livers were stored in RNAlater (Thermo Fisher Scientific, Burlington, ON, Canada) at $-20{ }^{\circ} \mathrm{C}$ until gene expression analysis ( $n=9$ per concentration). The gills ( $n=9$ per concentration) were stored at $-80{ }^{\circ} \mathrm{C}$ prior to homogenization for biomarker assays.

\section{Biomarker analyses}

Gill samples were homogenized at a 1:15 $(\mathrm{W} / \mathrm{V})$ ratio in $25 \mathrm{mM}$ HEPES-NaOH buffer (pH 7.4) containing $140 \mathrm{mM}$ $\mathrm{NaCl}, 0.1 \mathrm{mM}$ dithiothreitol, and $1 \mathrm{mg} / \mathrm{L}$ aprotinin. A subsample of the homogenate was centrifuged at $15,000 \times \mathrm{g}$ for $20 \mathrm{~min}$ at $2{ }^{\circ} \mathrm{C}$ and the supernatant (S15) was carefully collected to measure labile Zinc levels, cyclooxygenase (COX), and
glutathione-S-transferase (GST) activities. The remaining homogenates were used to determinate lipid peroxidation (LPO) and DNA damage (DNA strand breaks with the alkaline precipitation assay). Total protein concentrations were determined in the homogenate and the S15 fraction using standard solutions of albumin for calibration (Bradford 1976) and all samples were stored at $-80{ }^{\circ} \mathrm{C}$ after homogenization until further analysis.

DNA damage was assessed with a modified alkaline precipitation assay (Olive 1988; Gagné, 2014). A solution containing $200 \mu \mathrm{L}$ of $2 \%$ SDS, $10 \mathrm{mM}$ Tris, $10 \mathrm{mM}$ EDTA, and $40 \mathrm{mM} \mathrm{NaOH}$ was added to $25 \mu \mathrm{L}$ of gill homogenates and incubated for $1 \mathrm{~min}$. Then, $200 \mu \mathrm{L}$ of $120 \mathrm{mM} \mathrm{KCI}$ was added to the mixture, and samples were incubated at $60{ }^{\circ} \mathrm{C}$ for $10 \mathrm{~min}$. The DNA was precipitated by placing the samples on ice for $20 \mathrm{~min}$ and then centrifuging at $8000 \times \mathrm{g}$ and $4{ }^{\circ} \mathrm{C}$ for $5 \mathrm{~min}$. DNA strand breaks in the supernatant were detected using Hoechst dye (West et al. 1985). Therefore, $50 \mu \mathrm{L}$ supernatant was carefully removed and mixed with $150 \mu \mathrm{L}$ buffer containing $400 \mathrm{mM} \mathrm{NaCl}, 4 \mathrm{mM}$ cholate, $100 \mathrm{mM}$ Tris (pH 8.5), containing $1 \mu \mathrm{g} / \mathrm{mL}$ Hoechst (Thermo Fisher Scientific, Burlington, ON, Canada). Fluorescence was read at $360 \mathrm{~nm}$ excitation/ $460 \mathrm{~nm}$ emission using the Synergy 4 microplate reader (BioTek, Winooski, VT, USA). A salmon sperm DNA (Sigma-Aldrich, Oakville, ON, Canada) standard curve was used to quantify DNA content in supernatant. The data were expressed as $\mu \mathrm{g} \mathrm{DNA} / \mathrm{mg}$ proteins.

Lipid damage was determined by measuring lipid peroxidation (LPO) according to the thiobarbituric acid (TBARS) method (Wills 1987). Accordingly, $150 \mu \mathrm{L}$ of $20 \%$ trichloroacetic acid containing $2 \mathrm{mM} \mathrm{FeSO}_{4}$ and $75 \mu \mathrm{L}$ of $0.67 \%$ thiobabituric acid were added to $75 \mu$ gill homogenate. The mixture was incubated at $70{ }^{\circ} \mathrm{C}$ for $10 \mathrm{~min}$, cooled to room temperature and $100 \mu \mathrm{L}$ per sample was transferred to black half-area 96-well microplates. Fluorescence was determined at $540 \mathrm{~nm}$ excitation/ $600 \mathrm{~nm}$ emission using the Synergy 4 microplate reader (BioTek, Winooski, VT, USA). Blanks and standards of tetramethoxypropane (stabilized form of malonaldehyde) were prepared using homogenization buffer which was used as a standard. The data were expressed as nmol TBARS/ mg proteins.

Cyclooxygenase (COX) activity was determined using a microplate fluorescence procedure. The assay is based on 
the formation of $\mathrm{H}_{2} \mathrm{O}_{2}$ detected by the oxidation of 2,7dichlorofluorescein substrate in the presence of arachidonate and horseradish peroxidase (Fujimoto et al. 2002). Briefly, $25 \mu \mathrm{L}$ of the gill S15 fraction was mixed with $150 \mu \mathrm{L}$ of assay buffer consisting of $50 \mathrm{mM}$ Tris-Acetate, $0.5 \mathrm{mM}$ EDTA, and $0.1 \%$ Tween 20 ( $\mathrm{pH} \mathrm{8.0)}$. Then, $0.12 \mathrm{mM}$ arachidonate, $0.1 \mathrm{mM}$ dichlorofluorescein diactetate, and $0.1 \mu \mathrm{g} / \mathrm{mL}$ horseradish peroxidase in $50 \mathrm{mM} \mathrm{KH}_{2} \mathrm{PO}_{4}(\mathrm{pH} 8.0)$ are added. The reaction mixture was incubated for a total of $30 \mathrm{~min}$ at $25^{\circ} \mathrm{C}$, and the formation of fluorescein was measured every $2 \mathrm{~min}$ at $485 \mathrm{~nm}$ excitation and $520 \mathrm{~nm}$ emission using the Synergy 4 microplate reader (BioTek, Winooski, VT, USA). The data were expressed as relative fluorescein units $/ \mathrm{min} / \mathrm{mg}$ proteins.

Glutathione-S-transferase (GST) activity was determined using 1-chloro-2,4-dinitrobenzene (CDNB) as substrate (Gagne 2014). Briefly, $30 \mu \mathrm{L}$ S15 fraction was mixed with $200 \mu \mathrm{L} 1 \mathrm{mM}$ reduced L-glutathione (GSH), $1 \mathrm{mM}$ 1-chloro2,4-dinitrobenzene (CDNB), and $125 \mathrm{mM} \mathrm{NaCl}$ in $10 \mathrm{mM}$ HEPES (pH 6.5). Absorbance was read in clear microplates at $340 \mathrm{~nm}$ every $1 \mathrm{~min}$ for 30 min using the Synergy 4 microplate reader (BioTek, Winooski, VT, USA). The data were expressed as GSH (nmol) / $\mathrm{min} / \mathrm{mg}$ proteins.

Labile $\mathrm{Zn}$ levels in tissues were determined using the fluorescent probe N-(6-Methoxy-8-Quinolyl)-pToluenesulfonamide (TSQ) (Gagné and Blaise 1996). Accordingly, $20 \mu \mathrm{L}$ of the gill S15 fraction was combined with $80 \mu \mathrm{L}$ of $100 \mu \mathrm{M}$ TSQ, prepared in $20 \%$ DMSO in $5 \mathrm{mM} \mathrm{KH}_{2} \mathrm{PO}_{4}(\mathrm{pH} \mathrm{7.4)}$ and $140 \mathrm{mM} \mathrm{NaCl}$. The mixture was agitated for $5 \mathrm{~min}$ and fluorescence was determined in black 96-well half-area plates at $360 \mathrm{~nm}$ excitation/ $460 \mathrm{~nm}$ emission using the Synergy 4 microplate reader (BioTek, Winooski, VT, USA). Data were assessed using a zinc chloride (Sigma-Aldrich, Oakville, ON, Canada) standard curve and expressed as $\mathrm{ng} \mathrm{Zn} / \mathrm{mg}$ proteins.

\section{RNA extraction and reverse transcription}

Total RNA was extracted with the RNA Plus Mini kit and QIAShredder columns (QIAGEN, Toronto, ON, Canada) following the manufacturer's instructions. RNA was eluted in $30 \mu \mathrm{L}$ RNase-free water. RNA concentration and purity were measured with the NanoDrop 1000 (Thermo Fisher Scientific, Burlington, ON, Canada). A260/A280 ratios of samples were between 1.9-2.16. RNA concentration was adjusted to $40 \mathrm{ng} /$ $\mu \mathrm{L}$ for all samples.

Total RNA was reverse transcribed into cDNA using the Quanti-Tect ${ }^{\circledR}$ reverse transcription kit (QIAGEN, Toronto, ON, Canada) following the manufacturer's instructions. Briefly, $100 \mathrm{ng}$ RNA $(2.5 \mu \mathrm{L})$ was added to $2 \mu \mathrm{L} 7 \mathrm{x}$ genomic DNA wipe-out buffer and $9.5 \mu \mathrm{L}$ RNase-free water for a total volume of $14 \mu \mathrm{L}$ in thin-walled PCR tubes (Bio-Rad, Mississauga, ON, Canada). To eliminate genomic DNA, samples were placed on a thermocycler at $42{ }^{\circ} \mathrm{C}$ for $5 \mathrm{~min}$. Tubes were placed on ice and $4 \mu \mathrm{L}$ Quantiscript RT buffer, $1 \mu \mathrm{L}$ RT Primer Mix, and $1 \mu \mathrm{L}$ Quantiscript reverse transcriptase was added to the gDNA elimination reaction. The $\mathrm{RT}$ reaction was incubated at $42{ }^{\circ} \mathrm{C}$ for $15 \mathrm{~min}$, and then at $95^{\circ} \mathrm{C}$ for $3 \mathrm{~min}$ to inactivate the reverse transcriptase. All samples were diluted (1:10) with DEPC- $\mathrm{H}_{2} \mathrm{O}$ and stored at $-80^{\circ} \mathrm{C}$ before real-time quantitative PCR analysis (qPCR).

\section{Real-time qPCR}

Table 2 shows the selected genes for this study and their respective primers. Several primers have been previously published. We designed additional primer pairs using PrimerBLAST from NCBI (Primer3 with Blast; Rozen and Skaletsky, 2000). We assessed the absence of secondary structures using Netprimer (Biosoft, PaloAlto, CA, USA). We evaluated at least two primer pairs for each gene. All primers were synthetized by IDT, Integrated DNA Technologies (Coralville, IA, USA).

The qPCR analyses were performed using SsoFast EvaGreen Supermix (Bio-Rad, Mississauga, ON, Canada) and CFX96 Touch Real-Time PCR Detection System (BioRad). For each selected primer pair, a calibration curve (starting cDNA concentration: $2.5 \mathrm{ng}$, six serial dilutions, 2fold) was established to obtain PCR efficiency (values between 90 and 110\%) and limit of detection. Each reaction was run in duplicate and consisted of $5 \mu \mathrm{L}$ cDNA (equivalent to $2.5 \mathrm{ng}$ cDNA), $8 \mu \mathrm{L}$ SsoFast EvaGreen Supermix (dNTPs, Sso7d-fusion polymerase, $\mathrm{MgCl} 2$, EvaGreen dye), $300 \mathrm{nM} \mathrm{F}$ and R-primer, and DEPC-treated water (Thermo Fisher Scientific, Burlington, ON, Canada). Cycling parameters were $95^{\circ} \mathrm{C}$ for $2 \mathrm{~min}$, followed by 40 cycles of $95^{\circ} \mathrm{C}$ for $5 \mathrm{~s}, 60^{\circ} \mathrm{C}$ for $15 \mathrm{~s}$. Amplification specificity was verified with a melting oC fr: $95^{\circ} \mathrm{C}$ for $15 \mathrm{~s}, 57^{\circ} \mathrm{C}$ for $5 \mathrm{~s}$ and slowly reaching $95^{\circ} \mathrm{C}$ in $10 \mathrm{~min}$. Each plate included a no-template control.

\section{Data analysis}

Enzyme activity and other biomarker data were normalized with the total protein content of the homogenates while transcriptomic data were normalized by the reference genes. Normality and homogeneity of variances of the biomarker data were confirmed using the Shapiro-Wilk and Bartlett tests respectively. Difference between exposure concentration treatment groups of the REE mixture and controls was analyzed by one-way ANOVA and Tuckey's post hoc test. The data were expressed as the mean with standard error for $n=9$ individuals per treatment group. Data analysis was conducted with GraphPad Prism 8 (Version 8.4.0 (455) for Mac).

Data acquisition and analysis for gene expression data were performed with CFX Maestro (Bio-Rad, Mississauga, ON, Canada). Selected reference genes were elongation factor a (efla), hypoxanthine phosphoribosyl transferase (hprt), and 
Table 2 List of target and reference genes

\begin{tabular}{|c|c|c|c|c|c|}
\hline Genes of interest & Symbol & Function & $\begin{array}{l}\text { Forward-primer 5'-3' } \\
\text { Reverse-primer 5'-3' }\end{array}$ & $\begin{array}{l}\text { Amplicon } \\
\text { (bp) }\end{array}$ & Reference \\
\hline Catalase & CAT & Removal of $\mathrm{H} 2 \mathrm{O} 2$ & $\begin{array}{l}\text { F-TGATGTCACACAGG } \\
\text { TGCGTA } \\
\text { R-GTGGGCTCAGTGTT } \\
\text { GTTGAG }\end{array}$ & 195 & (Fontagne et al. 2008) \\
\hline Cytochrome $\mathrm{C}$ oxidase 1 & $\mathrm{CO} 1$ & Complex 4 of the respiratory chain & $\begin{array}{l}\text { F-ATCCTGTCGTTTGT } \\
\text { GTTGGC } \\
\text { R-GGTTGTGGAAGAGA } \\
\text { GAGTGGTT }\end{array}$ & 172 & In house \\
\hline Cytochrome P450 1A & CYP1A & $\begin{array}{l}\text { Hydroxylation of polaromatic } \\
\text { hydrocarbons }\end{array}$ & $\begin{array}{l}\text { F-GATGTCAGTGGCAG } \\
\text { CTTTGA } \\
\text { R-TCCTGGTCATCATG } \\
\text { GCTGTA }\end{array}$ & 104 & $\begin{array}{l}\text { (Aluru and Vijayan, } \\
\text { 2006) }\end{array}$ \\
\hline Ferritin $\mathrm{H}$ & $\mathrm{FeH}$ & $\mathrm{Fe}^{3+}$ homeostatis & $\begin{array}{l}\text { F-TGGGCAAAGAGAGC } \\
\text { ACATAGA } \\
\text { R-GGAACGGGAGGGAA } \\
\text { TAGCAT }\end{array}$ & 143 & In house \\
\hline Glutamate dehydrogenase & GLUD & Assimilation of ammonia & $\begin{array}{l}\text { F-TCGGAGGGGCTAAA } \\
\text { GCTGGTGT } \\
\text { R-TGTCACACATGCGT } \\
\text { GGGCGTT }\end{array}$ & 233 & (Dube et al. 2019) \\
\hline Glutathione-S-transferase-pi & GST & Conjugation of electrophiles & $\begin{array}{l}\text { F-ATTTTGGGACGGGC } \\
\text { TGACA } \\
\text { R-CCTGGTGCTCTGCT } \\
\text { CCAGTT }\end{array}$ & 81 & (Salaberria et al. 2009) \\
\hline Heat shock $70-\mathrm{kDa}$ protein & HSP70 & Protein chaperone & $\begin{array}{l}\text { F-ACCACACCCAGTTA } \\
\text { TGTCGCCT } \\
\text { R-CTTCCGCCCTATCA } \\
\text { GCCGC }\end{array}$ & 123 & (Dube et al. 2019) \\
\hline DNA Ligase & LIG & DNA repair & $\begin{array}{l}\text { F-TGGTGCGATTTTGA } \\
\text { AGTGTG } \\
\text { R-GGTCCTGTGTCCTT } \\
\text { GTGGTT }\end{array}$ & 147 & (Gagne et al. 2012) \\
\hline Metallothionein & MT & Divalent metals homeostasis & $\begin{array}{l}\text { F-GCTCTAAAACTGGC } \\
\text { TCTTGC } \\
\text { R-GTCTAGGCTCAAGA } \\
\text { TGGTAC }\end{array}$ & 236 & (Gagne et al. 2012) \\
\hline $\begin{array}{l}\text { Proliferating cell nuclear } \\
\text { antigen }\end{array}$ & PCNA & Cell proliferation & $\begin{array}{l}\text { F-CAGAGGACAACGCA } \\
\text { GACACA } \\
\text { R-CACGGCAGATACGG } \\
\text { GCAAAC }\end{array}$ & 156 & (Gagne et al. 2013) \\
\hline $\begin{array}{l}\text { Superoxide dismutase } \\
\text { (Cu/Zn cytosolic) }\end{array}$ & SOD & Oxygen radical scavenger & $\begin{array}{l}\text { F-TGGTCCTGTGAAGC } \\
\text { TGATTG } \\
\text { R-TTGTCAGCTCCTGC } \\
\text { AGTCAC }\end{array}$ & 201 & (Fontagne et al. 2008) \\
\hline $\begin{array}{l}\text { Secreted acidic cysteine rich } \\
\text { glycoprotein }\end{array}$ & SPARC & Collagen and bone formation & $\begin{array}{l}\text { F-TCACCCTGTACGAG } \\
\text { CGCGATGA } \\
\text { R-AGCTGACCGAACTG } \\
\text { CCAGTGGA }\end{array}$ & 187 & (Dube et al. 2019) \\
\hline $\begin{array}{l}\text { Signal transducer \& activator } \\
\text { of transcription } 3\end{array}$ & STAT3 & Response to cytokines, immunity & $\begin{array}{l}\text { F-TGAGCCCTAAGCCT } \\
\text { CCTGTT } \\
\text { R-TCCCACTGATGTCC } \\
\text { TTTTCCAC }\end{array}$ & 99 & In house \\
\hline Ubiquitin & UB & Protein tag for degradation & $\begin{array}{l}\text { F-CTACGCTCGCCTCC } \\
\text { ATCCT } \\
\text { R-CCACAAAAAGCACC } \\
\text { AAGCCAA }\end{array}$ & 96 & In house \\
\hline \multicolumn{6}{|l|}{ Reference genes } \\
\hline Elongation factor I $\alpha$ & $\mathrm{EF} 1 \alpha$ & $\begin{array}{l}\text { Aminoacyl tRNA transfer to } \\
\text { ribosome }\end{array}$ & $\begin{array}{l}\text { F-GAATCGGCTATGCC } \\
\text { TGGTGAC } \\
\text { R-GGATGATGACCTGA } \\
\text { GCGGTG }\end{array}$ & 141 & $\begin{array}{l}\text { (Bower and Johnston, } \\
\text { 2009) }\end{array}$ \\
\hline $\begin{array}{l}\text { Hypoxanthine phosphoribosyl } \\
\text { transferase I }\end{array}$ & HPRT & Purines salvage pathway & $\begin{array}{l}\text { F-CCGCCTCAAGAGCT } \\
\text { ACTGTAAT } \\
\text { R-GTCTGGAACCTCAA } \\
\text { ACCCTATG }\end{array}$ & 255 & $\begin{array}{l}\text { (Bower and Johnston, } \\
\text { 2009) }\end{array}$ \\
\hline Prolylpeptidyl isomerase I & PPIA & Protein folding of new proteins & $\begin{array}{l}\text { F-CATCCCAGGTTTCA } \\
\text { TGTGC } \\
\text { R-CCGTTCAGCCAGTC } \\
\text { AGTGTT }\end{array}$ & 203 & $\begin{array}{l}\text { (Bower and Johnston, } \\
\text { 2009) }\end{array}$ \\
\hline
\end{tabular}


prolylpeptidyl isomerase I (ppia). Genes were analyzed for their stability across the samples using the reference gene selection tool included in the CFX Maestro software (Bio-Rad). The data were normalized against housekeeping genes and expressed as fold changes of the control. Efficiencies obtained from the standard curves were entered manually to correct the $\mathrm{Cq}$ values. An ANOVA with a Tuckey's post hoc test was performed on the gene expression data using CFX Maestro to account for significant changes between concentrations of the REE mixture. A Pearson's correlation analysis was performed using GraphPad Prism 8 to determine significant relationships between gene expression data and biomarkers. Significance was set at $p<0.05$ for all analyses.

\section{Results}

\section{Acute toxicity of the REE mixture}

The highest concentration tested solely for the determination of an $\mathrm{LC}_{50}$ was $100 \mathrm{x}$. The LC50 value was $60 \mathrm{X}$ of the REEs mixture corresponding to the $18.2 \mathrm{mg} / \mathrm{L} \mathrm{Ce}, 9.0 \mathrm{mg} / \mathrm{L} \mathrm{La}$, $7.5 \mathrm{mg} / \mathrm{L} \mathrm{Nd}, 1.8 \mathrm{mg} / \mathrm{L} \mathrm{Pr}$, and $1.5 \mathrm{mg} / \mathrm{L} \mathrm{Sm}$ (Table 3). The reported LC50 for the single REEs was included and revealed that $\mathrm{Sm}$ concentration in the mixture $(1.36 \mathrm{mg} / \mathrm{L})$ corresponded to the LC50 of Sm alone $(1.6 \mathrm{mg} / \mathrm{L})$ suggesting that toxicity was mainly samarium-driven in this mixture. The LC50 value of $\operatorname{Pr}$ alone $(5.48 \mathrm{mg} / \mathrm{L})$ was close to the Pr levels in the mixture $(1.68 \mathrm{mg} / \mathrm{L})$ suggesting some contribution of this element.

We examined the expression of 14 genes of interest in rainbow trout liver samples (Fig. 1). We observed an upregulation of expression for all concentrations of the mixture for catalase (CAT), an enzyme protecting cells from oxidative stress (Fig. 1a). The genes for the $70 \mathrm{kDa}$ heat shock protein ( $h s p 70$ ) and glutamate dehydrogenase ( $g l u d$ ) were also upregulated at 10x concentration (Fig. 1a). Glutathione Stransferase $(g s t)$, an enzyme responsible for detoxification of

Table 3 Reported LC50 values of the selected REEs

\begin{tabular}{lll}
\hline REE & LC50 individual (mg/L) & LC50 values of mixture (60X) \\
\hline $\mathrm{La}$ & $120^{\mathrm{a}}$ & 8.4 \\
$\mathrm{Ce}$ & $95^{\mathrm{a}}$ & 7.8 \\
$\mathrm{Nd}$ & $60^{\mathrm{a}}$ & 7.2 \\
$\mathrm{Sm}$ & 1.6 & 1.36 \\
$\mathrm{Pr}$ & $5.48^{\mathrm{b}}$ & 1.68 \\
& & Total: $26.44 \mathrm{mg} / \mathrm{L}$ \\
\hline
\end{tabular}

${ }^{a}$ From Dubé et al. (2019), obtained from the acute/genomic threshold ratio. b. From the linear relationship between Hydra and rainbow trout (Blaise et al. 2018) electrophilic compounds, was downregulated (Fig. 1b). Metallothionein $(m t)$, a protein involved in divalent metal detoxification, was also downregulated in fish exposed to the $1 \mathrm{X}$ concentration (Fig. 1b). The remaining nine genes of interest were not significantly changed in the mixture at the concentrations used (Fig. 1c). Correlation analysis between the gene expression data revealed that the following pairs were strongly correlated $(r>0.5 ; p<0.001): u b$ and $f e ;$ stat 3 and $p c n a ;$ stat 3 and lig; hsp-lig; hsp-glud; and hsp-gst. The influence of these genes was examined based on the number of correlation with other biomarkers: $\operatorname{glud}(8)=h s p 70(8)<\operatorname{cat}(7)=\operatorname{lig}(7)=$ labile $\mathrm{Zn}<\operatorname{sparc}(6)<$ others. If we consider the gene transcripts that were significantly changed by the REEs with influence potential, we obtain the following: cat, $h s p 70$, and labile $\mathrm{Zn}$. Hence, exposure to REEs leads to changes in reactive oxygen handling (cat), protein denaturation, and altered ammonium/ $\mathrm{Zn}$ metabolism. Because of the strong correlations with some of these endpoints, we cannot exclude effects on lig and gst.

\section{Biomarker responses}

DNA damage was measured using the alkaline precipitation assay in fish exposed to the REE mix (Fig. 2). The assay revealed DNA strand breaks at the highest concentration tested (10X). Electrophile conjugation (GST), inflammation (COX), oxidative stress (LPO), and intracellular labile zinc levels were analyzed after exposure to the REE mixture (Fig. 3a-d). COX activity showed a significant increase at a concentration threshold of $0.32 \mathrm{X}$ as determined by the Tuckey's difference multiple comparisons test (Fig. 3a; $\operatorname{COX} p=0.03$ ). GST activity and LPO were not significantly affects by the REEs (Fig. $3 b$ and c). Labile Zn levels were readily increased for all concentrations $(<0.1 \mathrm{X})$. Correlation analysis revealed that the biochemical biomarkers were correlated between COX and GST activities $(r=0.68)$ (Table 4). Other strong correlations (i.e., $r>0.5 ; p<0.01)$ were found for labile $\mathrm{Zn}$ and sparc $(r=0.51)$, and $\operatorname{sod}(r=0.55)$ and $m t$ gene expression in the liver $(r=-0.31 ; 0.1<p<0.05)$. DNA strand breaks were, however, significantly correlated with GST $(r=0.48)$ and COX $(r=0.42)$ activities suggesting the involvement of oxidative stress.

Principal component analysis was also performed to determine the biomarkers with the highest factorial weights (explaining the variance) and relationships between biomarkers (Fig. 4). The total variance was explained by $65 \%$ with 3 factors. The most important biomarkers (factorial weights $>0.7$ in one of the 3 factors) were GST activity, DNA damage, $h s p 70$, sparc, $u b$, lig, labile $\mathrm{Zn}, m t$, and glud. The most important biomarkers were distributed in 3 distinct clusters or groups. The first cluster consisted in the lig, sparc, glud, labile $\mathrm{Zn}$, and $h s p 70$. The second cluster consisted in GST activity and $u b$. The third cluster involved $m t$ and DNA damage. This suggests that these changes were able to explain 
a-Upregulated genes

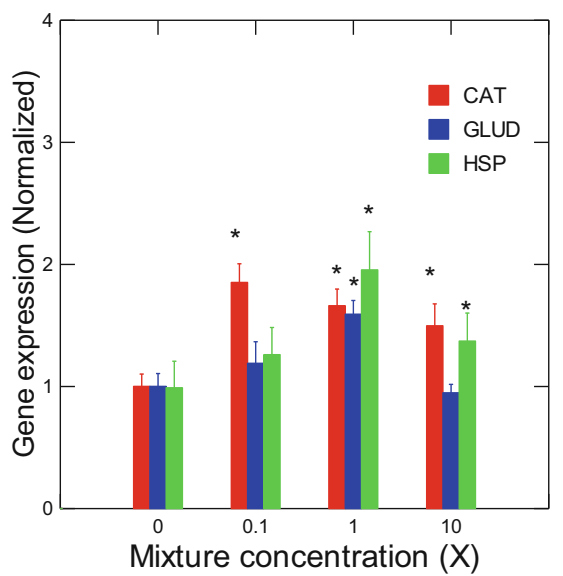

b-Downregulated genes

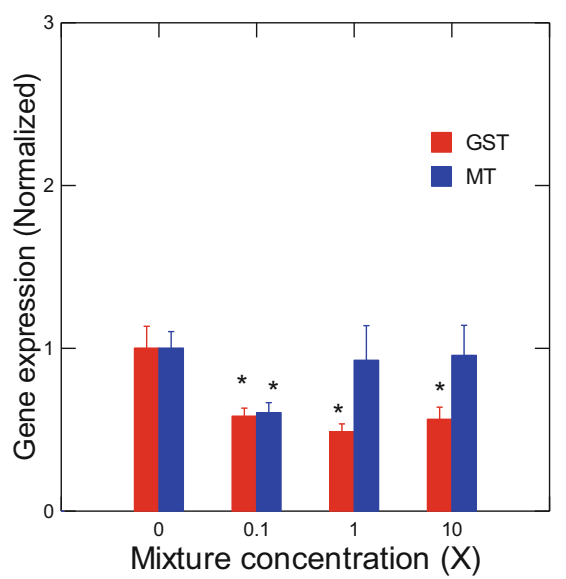

c-Unaffected genes

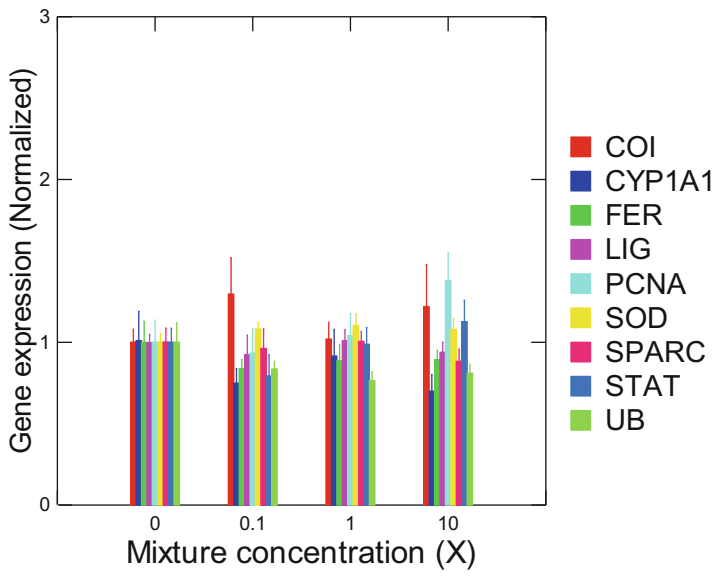

Fig. 1 Gene expression changes induced by exposure to a REE mixture in rainbow trout liver. a Genes that were significantly upregulated in one or more concentrations of the mixture included CAT, GLUD, and HSP70. b Genes that were significantly downregulated in one or more concentrations of the mixture included GST and MT. c Genes without significant gene expression changes in any of the concentrations tested. The data represent the mean \pm SEM. Asterisks (*) indicate a significant difference from the negative controls most of the variance $(65 \%)$ and includes the biomarkers found during above analysis in respect to the endpoints showing the highest number of correlations and changes with the exposure concentration. Cat was identified as one of the mostly correlated response biomarker and showed a factorial weight close to 0.7 at 0.68 and was closely associated with $h s p 70$.

\section{Discussion}

The adverse effects of REE on aquatic and terrestrial organisms were studied mostly in organisms exposed to single elements and many studies involved La and Ce only (Gonzalez et al. 2014). Previous studies on the toxicity and mechanisms of action of these elements revealed that each REEs might have distinct effects, complicating the identification of a universal mode of toxicity for this family. It is noteworthy that gene expression was determined in the liver while the biochemical biomarkers were done in gills tissues to satisfy tissue mass requirements to perform all the assays. Hence, this could introduce tissue discrepancy variations in the observed responses. The electronegativity and ionic radius (those close to calcium) were able to predict loss of survival in juvenile rainbow trout and Hydra (Dubé et al. 2019; Blaise et al. 2018). Based on the threshold concentration producing effects at the molecular level and toxicity (LC50), sublethal (chronic) effects were found at concentrations 600 times below the toxicity values in the present study suggesting that effects are likely to occur at in contaminated lakes by mining activities. The $1 \mathrm{X}$ mix corresponded to the 5 most abundant elements based on lakes concentrations under the influence of mining activities, hence the levels were higher than in undisturbed environments (Beaubien 2015). The ratio between sublethal effects and toxicity was higher than those obtained with single REEs with a ratio of 120 (Dubé et al. 2019). In some cases, gene expression was increased at lower concentrations followed by a decrease in expression. This suggests that the responses occurred at low concentration and reached saturation and exhausting of responses at higher concentrations.

Based on the relative concentrations of the REE of the mixture, the concentration of $\mathrm{Sm}$ in the mixture was very close to the LC50 of Sm in trout juveniles (Table 3). In trout exposed to Sm alone, cyp1A1, DNA damage (gadd45), gst, $h s p 70$, and $m t$ were upregulated and cat, glud genes were downregulated. In the present study, gst and $m t$ were downregulated while cat, glud, and $h s p 70$ were upregulated indicating that only $h s p 70$ gene expression agreed with the present study. This suggests that other effects from the other elements in the mixture were at play. Thus, $h s p 70$ and DNA repair genes were affected by all of the individual 7 REEs examined (Dubé et al. 2019), which is consistent with the effects observed with $h s p 70$, lig, and DNA damage data in the present study. If this holds true, REE mixtures could 
Table 4 Correlation analysis of biomarker and gene expression data. Pearson's $r$ (white) and $p$ value (gray) are given for each pair. $p$ values of significant correlations $(p<0.05)$ are highlighted in red. That CAT was significantly correlated with CO1 $(r=0.48)$, GLUD $(r=0.47)$, GST $(r=$ $-0.39)$, HSP70 $(r=0.39)$, and SOD $(r=0.34)$. Mitochondrial CO1 was significantly correlated with

\begin{tabular}{|c|c|c|c|c|c|c|c|c|c|c|c|c|c|c|c|c|c|c|}
\hline & \multicolumn{4}{|c|}{ Enzyme activity (gills) } & \multicolumn{14}{|c|}{ Gene expression (liver) } \\
\hline & GST & LPO & APA & $\mathrm{Zn}$ & CAT & CO1 & $\begin{array}{r}\text { CYP } \\
1 \mathrm{~A} \\
\end{array}$ & Fer $\mathrm{H}$ & GLUD & GST & HSP & Lig & MT & PCNA & SOD & SPARC & Stat3 & Ub \\
\hline \multirow[t]{2}{*}{ COX } & 0.68 & 0.39 & 0.42 & 0.22 & -0.05 & 0.13 & 0.02 & 0.25 & -0.12 & -0.01 & 0.13 & 0.15 & -0.05 & 0.16 & 0.18 & 0.10 & 0.00 & 0.20 \\
\hline & $<0.01$ & 0.03 & 0.011 & 0.22 & 0.78 & 0.45 & 0.93 & 0.15 & 0.48 & 0.97 & 0.45 & 0.39 & 0.78 & 0.36 & 0.30 & 0.58 & 0.99 & 0.24 \\
\hline \multirow{2}{*}{ GST } & & 0.27 & 0.48 & 0.29 & 0.02 & 0.32 & -0.30 & 0.28 & -0.18 & -0.15 & 0.19 & 0.23 & 0.01 & 0.42 & 0.12 & 0.17 & 0.20 & 0.17 \\
\hline & & 0.13 & $<0.01$ & 0.10 & 0.93 & 0.06 & 0.08 & 0.10 & 0.29 & 0.39 & 0.28 & 0.17 & 0.98 & $<0.01$ & 0.50 & 0.32 & 0.23 & 0.32 \\
\hline \multirow[t]{2}{*}{ LPO } & & & 0.20 & 0.01 & -0.11 & 0.14 & 0.15 & 0.01 & 0.17 & -0.10 & 0.35 & 0.45 & -0.31 & 0.16 & -0.31 & 0.1 & 0.16 & -0.18 \\
\hline & & & 0.10 & 0.97 & 0.52 & 0.45 & 0.39 & 0.94 & 0.34 & 0.58 & 0.05 & 0.01 & 0.07 & 0.37 & 0.07 & 0.57 & 0.37 & 0.32 \\
\hline \multirow[t]{2}{*}{$A P A$} & & & & 0.00 & 0.14 & 0.23 & -0.10 & 0.11 & 0.11 & -0.2 & 0.27 & 0.17 & 0.04 & 0.29 & 0.21 & 0.02 & 0.20 & -0.01 \\
\hline & & & & 0.99 & 0.42 & 0.17 & 0.56 & 0.54 & 0.54 & 0.24 & 0.12 & 0.31 & 0.82 & 0.09 & 0.22 & 0.65 & 0.23 & 0.96 \\
\hline \multirow[t]{2}{*}{$Z n$} & & & & & 0.39 & 0.38 & -0.27 & -0.12 & 0.19 & -0.31 & 0.37 & 0.38 & -0.30 & 0.37 & 0.551 & 0.514 & 0.249 & -0.031 \\
\hline & & & & & 0.02 & 0.03 & 0.12 & 0.51 & 0.29 & 0.08 & 0.04 & 0.03 & 0.08 & 0.04 & 0.001 & 0.002 & 0.162 & 0.862 \\
\hline \multirow[t]{2}{*}{ CAT } & & & & & & 0.42 & 0.07 & -0.24 & 0.47 & -0.39 & 0.39 & 0.19 & -0.27 & -0.03 & 0.339 & 0.195 & -0.044 & -0.157 \\
\hline & & & & & & 0.01 & 0.67 & 0.17 & $<0.01$ & 0.02 & 0.03 & 0.27 & 0.11 & 0.84 & 0.043 & 0.255 & 0.799 & 0.361 \\
\hline \multirow[t]{2}{*}{$c 01$} & & & & & & & -0.07 & 0.11 & 0.12 & -0.14 & 0.46 & 0.48 & -0.24 & 0.13 & 0.135 & 0.361 & 0.207 & 0.174 \\
\hline & & & & & & & 0.69 & 0.51 & 0.5 & 0.42 & $<0.01$ & $<0.01$ & 0.16 & 0.46 & 0.432 & 0.031 & 0.226 & 0.31 \\
\hline \multirow[t]{2}{*}{ CYP1A } & & & & & & & & -0.34 & 0.38 & 0.21 & 0.05 & 0.13 & -0.26 & -0.27 & -0.052 & 0.076 & 0.042 & -0.315 \\
\hline & & & & & & & & 0.04 & 0.02 & 0.23 & 0.78 & 0.45 & 0.12 & 0.11 & 0.765 & 0.66 & 0.809 & 0.061 \\
\hline \multirow[t]{2}{*}{ Fer $H$} & & & & & & & & & -0.36 & 0.14 & -0.19 & 0.09 & 0.29 & -0.12 & 0.11 & -0.05 & -0.08 & 0.76 \\
\hline & & & & & & & & & 0.03 & 0.41 & 0.27 & 0.60 & 0.09 & 0.48 & 0.51 & 0.76 & 0.65 & $<0.01$ \\
\hline \multirow[t]{2}{*}{ GLUD } & & & & & & & & & & -0.38 & 0.58 & 0.39 & -0.12 & 0.14 & 0.04 & 0.41 & 0.31 & -0.40 \\
\hline & & & & & & & & & & 0.02 & $<0.01$ & 0.02 & 0.49 & 0.41 & 0.81 & 0.01 & 0.07 & 0.02 \\
\hline \multirow[t]{2}{*}{ GST } & & & & & & & & & & & -0.51 & -0.1 & 0.23 & -0.24 & 0.03 & -0.21 & -0.04 & 0.39 \\
\hline & & & & & & & & & & & $<0.01$ & 0.57 & 0.17 & 0.15 & 0.88 & 0.22 & 0.8 & 0.02 \\
\hline \multirow[t]{2}{*}{ HSP70 } & & & & & & & & & & & & 0.51 & -0.01 & 0.38 & -0.02 & 0.44 & 0.33 & -0.27 \\
\hline & & & & & & & & & & & & $<0.01$ & 0.94 & 0.02 & 0.93 & 0.01 & 0.05 & 0.11 \\
\hline \multirow[t]{2}{*}{ Ligase } & & & & & & & & & & & & & -0.16 & 0.30 & 0.06 & 0.56 & 0.52 & 0.05 \\
\hline & & & & & & & & & & & & & 0.37 & 0.08 & 0.74 & $<0.01$ & 0.001 & 0.76 \\
\hline \multirow[t]{2}{*}{ MT } & & & & & & & & & & & & & & 0.27 & -0.22 & -0.36 & 0.08 & 0.41 \\
\hline & & & & & & & & & & & & & & 0.11 & 0.19 & 0.03 & 0.64 & 0.01 \\
\hline \multirow[t]{2}{*}{ PCNA } & & & & & & & & & & & & & & & -0.08 & 0.24 & 0.50 & -0.13 \\
\hline & & & & & & & & & & & & & & & 0.63 & 0.16 & $<0.01$ & 0.46 \\
\hline \multirow[t]{2}{*}{$S O D$} & & & & & & & & & & & & & & & & 0.19 & -0.15 & 0.10 \\
\hline & & & & & & & & & & & & & & & & 0.27 & 0.39 & 0.56 \\
\hline \multirow[t]{2}{*}{ SPARC } & & & & & & & & & & & & & & & & & 0.30 & -0.07 \\
\hline & & & & & & & & & & & & & & & & & 0.08 & 0.71 \\
\hline \multirow[t]{2}{*}{ Stat3 } & & & & & & & & & & & & & & & & & & -0.06 \\
\hline & & & & & & & & & & & & & & & & & & 0.75 \\
\hline
\end{tabular}

denature proteins ( $h s p 70)$ and damage DNA in juvenile trout. This was further corroborated with the significant correlation between $h s p 70$ gene expression and the LC50 in rainbow trout juveniles exposed to 7 REEs (Dubé et al. 2019). Rainbow trout eggs have been shown to be very sensitive to $\mathrm{La}$ with an $\mathrm{LC}_{50}$ of $0.02 \mathrm{mg} / \mathrm{L} \mathrm{La}$ in a 28 -day study (Birge et al. 1979) corresponding to about $0.15 \mathrm{X}$ of

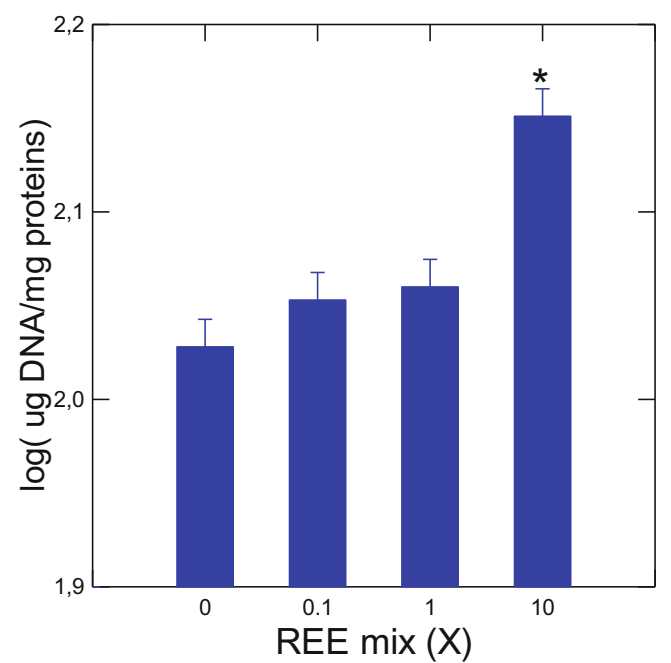

Fig. 2 Evaluation of DNA strand breaks after $96 \mathrm{~h}$ exposure to a REE mixture in rainbow trout gills with the alkaline precipitation assay. Histograms show standard mean \pm SEM. Significance was set at $p<0.05$ the REEs mixture in the present study. Although three out of the five REEs in our mixture ( $\mathrm{La}, \mathrm{Ce}, \mathrm{Nd}$ ) had very high $\mathrm{LC}_{50}$ values individually, the mixture of five REEs induced significant effects in a number of genes at concentrations below the environmental level. One possible factor that could have influenced toxicity at high concentrations (LC50 assessment) is in the precipitation of REEs by the presence of phosphates in the exposure medium. Phosphate levels were below the detection limit $(<0.05 \mathrm{mg} / \mathrm{L})$ in aquarium water, hence unlikely to cause significant precipitation. However, in a previous study by the same laboratory, evidence of precipitation was sometimes observed at concentrations $>40 \mathrm{mg} / \mathrm{L}$ in the same aquarium water of the present study (Dubé et al. 2019). The actual concentration in water for $\mathrm{Sm}$ and Ce was $38 \%$ and $35 \%$ of the nominal (added) concentration respectively but at concentrations $>40 \mathrm{mg} / \mathrm{L}$. At concentrations below $40 \mathrm{mg} / \mathrm{L}$, the measured concentration was between 75 and $104 \%$ of the nominal concentrations. Since the observed effects occurred at concentrations well below the LC50 for $\mathrm{Sm}$, no precipitation was expected and no evidence of precipitation was observed at concentrations below $60 \mathrm{X}$.

In the present study, the mixture of five REEs seemed to induce oxidative stress in the liver even below environmental levels $(<1 \mathrm{X})$. While LPO in gills and sod expression in the liver remained unaffected, we observed a significant hepatic 


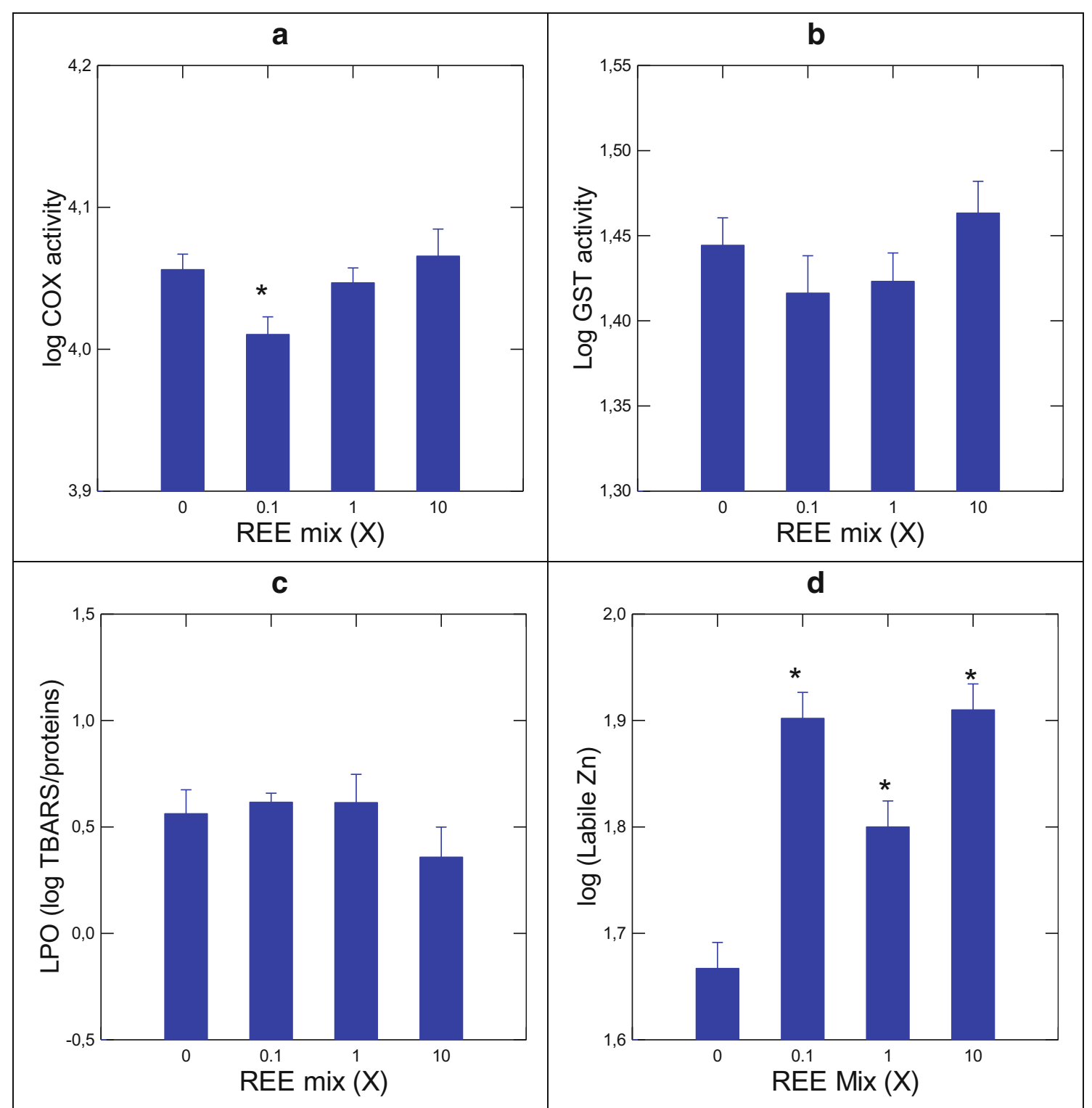

Fig. 3 Evaluation of changes in enzyme activities and labile zinc levels in rainbow trout gills after 96 h exposure to a REE mixture. Histograms show standard mean $\pm \mathrm{SEM}$. The units for labile $\mathrm{Zn}$ were $\mathrm{ng} \mathrm{Zn} / \mathrm{mg}$ proteins). Significance was set at $p<0.05$

upregulation of cat and downregulation in gst and $m t$ expressions for the selected concentrations of the mixture. In mice fed $\mathrm{La}, \mathrm{Ce}$, or $\mathrm{Nd}$, oxidative stress was observed in the liver as demonstrated changes in the activities of SOD, CAT, glutathione peroxidase, glutathione (GSH), and LPO (Huang et al. 2011). Zebra mussels have shown antioxidant or prooxidant activity depending on La concentrations (Hanana et al. 2017). Although some evidence of oxidative stress was shown, other studies demonstrated, however, opposite antioxidant effects (Pagano et al. 2015). REEs have displayed hormetic effects related to oxidative status and antioxidant capacities on multiple occasions (Gonzalez et al. 2014). Based on the lack of LPO, our data support the notion that the REEs mixture did not produce oxidative damage. This suggests that the REE mixture displayed no antioxidant effects. However, the increase of labile $\mathrm{Zn}$ in the gills with the absence of $m t$ gene expression in the liver suggests that the REEs were able to increase the labile fraction of $\mathrm{Zn}$ and sparc expression (cysteine-rich osteonectins) in cells perhaps through REE displacement of bound $\mathrm{Zn}$ to proteins such as osteonectins and $\mathrm{Cu}, \mathrm{Zn}-\mathrm{SOD}$. Indeed, the levels of labile $\mathrm{Zn}$ were strongly correlated with sod and sparc expressions suggesting involvement of antioxidant responses and interaction with collagen and $\mathrm{Ca}$ fixation in bones. More research will be needed to examine the interaction of REE to osteonectins. It was shown that La could bind to collagen mimicking peptides (Sun et al. 2019) which are related to sparc gene expression. However, it is not known if the other REEs, especially Sm, could bind collagen and produce changes in sparc gene expression. Other REEs ions were shown to bind collagen peptides 


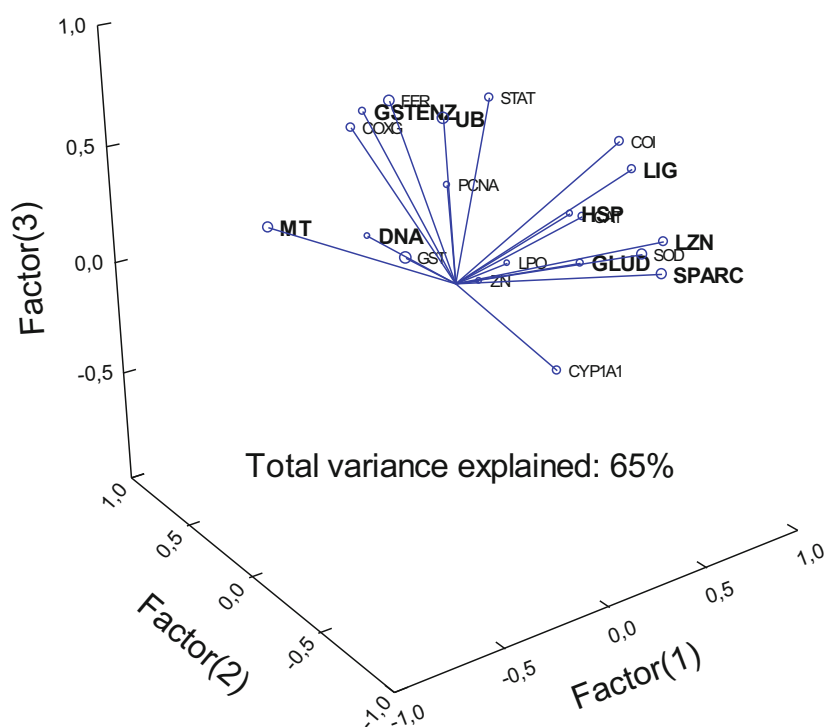

Fig. 4 Principal components of biomarker data. The total explained variance was $65 \%$ by 3 components (axes). Biomarkers with the factorial weights $>0.7$ are highlighted in bold

forming helical nanoropes (He et al. 2016). The lanthanides that promoted the winding of collagen peptide into nanoropes were $\mathrm{La}, \mathrm{Eu}$, and $\mathrm{Tb}$. Recent evidence showed that gadolinium, La, and terbium could promote bone formation as they serve as templates to initiate osteogenesis in mammalian organisms (Liao et al. 2019; Hu et al. 2018; Liu et al. 2014). However, this has yet to be observed directly in aquatic organisms and the present data suggests that similar effects could be observed in fish. Sparc codes for osteonectin, a high affinity collagen binding glycoprotein that fixes calcium, initiate mineralization and promotes crystal formation. Sparc gene expression was one the most influential responses according to principal component analysis, strength and number of correlations in the present study. The impacts of REEs on bone/shell growth should be examined more closely in future work.

Genes involved in detoxification and oxidative stress $(m t$ and $G S T$ ) was downregulated at low concentrations of the mixture. The downregulation of MT gene expression was consistent with the increase in labile $\mathrm{Zn}$ but was only marginally correlated $(r=-0.30 ; p=0.08)$. In zebra mussels exposed to $\mathrm{Sm}$, an upregulation of gst gene expression was observed at $>10 \mu \mathrm{g} / \mathrm{L}$ (Hanana et al. 2018), while La decreased GST activity at the highest concentration tested $(1250 \mu \mathrm{g} / \mathrm{L})$ after 14 days (Hanana et al. 2017). MT levels were not affected by La in the exposure conditions chosen (Hanana et al. 2017) but were induced in juvenile fish exposed to Sm (Dubé et al. 2019). Mt gene expression was not correlated with any of the other end points with the exception with SPARC gene expression $(r=-0.36)$. The relationship between them, if any, is not clear. Both encode for cysteine containing proteins involving perhaps the binding of Ca ions (Sage et al. 1989) and perhaps $\mathrm{Cu}^{2+}$ or $\mathrm{Zn}^{2+}$ as with MT. The extracellular matrix contains also various metalloproteases $(\mathrm{Zn}$ ?) which are involved in the de-gelation of the extracellular matrix promoting permeation by (cancerous) cells in tissues (Velasco et al. 2000). A double role for MT, one of protection and promotion, in carcinogenesis, has been proposed (Rodrigo et al. 2020). This suggests that REEs could disrupt cell differentiation and proliferation processes.

Exposure of rainbow trout juvenile lead to the formation of DNA strand breaks although no increase in lig gene expression was observed. The genotoxic potential was previously reported in trout exposed to Sm, gadolinium, cerium, La, erbium, and neodymium based on gadd45 (growth arrested DNA repair activity) gene expression (Dubé et al. 2019). The expression of gadd45 was expressed at a threshold concentration of $0.12 \mathrm{mg} / \mathrm{L}$ corresponding to a $5 \mathrm{X}$ concentration in the REEs mixture based on Sm. Sm significantly decreased strand breaks at $0.25 \mathrm{mg} / \mathrm{L}$ (corresponding to $10 \mathrm{X}$ concentration of the REEs mixture) in mussels compared to controls suggesting decreased repair activity (Hanana et al. 2018). The same calculation was made for $\mathrm{La}(8 \mathrm{X}), \mathrm{Ce}(13 \mathrm{X}), \mathrm{Nd}(5 \mathrm{X})$. Based on the composition of the REEs mixture, $\mathrm{Sm}, \mathrm{Nd}$, and La could explain the levels in DNA strand breaks observed at 10X. Genotoxicity has been previously observed for Ce but not La such as mitotic aberrations in sea urchin embryos at $1.4 \mathrm{mg} / \mathrm{L}$ corresponding to the $5 \mathrm{X}$ concentration of the mixture (Oral et al. 2010). Micronuclei and chromosomal aberrations in bone marrow of mice exposed to $\operatorname{Pr}(\mathrm{III})$ and $\mathrm{Nd}$ (III) in intraperitoneal injected mice (Jha and Singh 1995). However, La did not display genotoxic effects in zebra mussel when assessing DNA strand breaks up to concentrations of $1.25 \mathrm{mg} / \mathrm{L}$ (Hanana et al. 2017). Based on these studies, the following REEs would be the most suspect in respect to genotoxicity: $\mathrm{Sm}, \mathrm{Nd}$, and $\mathrm{Ce}$.

\section{Conclusions}

The data revealed that the effects of REEs on fish survival could be explained by Sm with no evidence of synergitic or antoganist effects in rainbow trout juveniles. Gene expression and biochemical markers revealed that sublethal effects could be shown at concentration 600 times less than the acute lethality. This corresponds to concentrations of REEs mixture below $1 \mathrm{X}$ suggesting the possibility of toxic effects in the environment especially those contaminated by mining activities. The major sublethal effects involved the following pathways: DNA strand breaks (genotoxicity), labile Zn, cat, gst, hsp70, sparc, $m t$, and glud as determined by principal component analysis and concentration-dependent effects. The results suggest that REE mixtures and these effects are likely to occur in environments under the influence of mining activities. 
Authors' contributions HH planned the experiments, performed the biomarker analyses, data analysis, and manuscript preparation. CK provided support for data analysis and manuscript preparation. FG is the principle investigator and participated to data statistical analyses and manuscript preparation.

Funding This research was funded under the Chemical Management Plan for rare earth elements of Environment and Climate Change Canada.

Data availability The data are available upon demand by request to the corresponding author.

\section{Compliance with ethical standards}

Competing interests The authors declare that they have no competing interests.

\section{Ethics approval and consent to participate Not applicable.}

\section{Consent for publication Not applicable.}

Open Access This article is licensed under a Creative Commons Attribution 4.0 International License, which permits use, sharing, adaptation, distribution and reproduction in any medium or format, as long as you give appropriate credit to the original author(s) and the source, provide a link to the Creative Commons licence, and indicate if changes were made. The images or other third party material in this article are included in the article's Creative Commons licence, unless indicated otherwise in a credit line to the material. If material is not included in the article's Creative Commons licence and your intended use is not permitted by statutory regulation or exceeds the permitted use, you will need to obtain permission directly from the copyright holder. To view a copy of this licence, visit http://creativecommons.org/licenses/by/4.0/.

\section{References}

Beaubien C (2015) Toxicité de deux lanthanides (La, Ce) sur l'algue verte Chlorella fusca. Master Thesis. Université du Québec Institut National de la Recherche Scientifique Centre Eau Terre Environnement, $128 \mathrm{pp}$.

Binnemans K, Jones PT, Blanpain B, van Gerven T, Yang Y, Walton A, Buchert M (2013) Recycling of rare earths: a critical review. J Clean Prod 51:1-22

Birge WJ, Black JA, Westerman AG (1979) Evaluation of aquatic pollutants using fish and amphibian eggs as bioassay organisms In: Nielssen WS , Migaki G, Scarpelli DG (Eds.), Animal as Monitors of Environmental Pollutants, National Academy of Sciences, Washington, D.C, pp. 108-118

Blaise C, Gagné F, Férard JF, Eullaffroy P (2008) Ecotoxicity of selected nano-materials to aquatic organisms. Environ Toxicol 23:591-598

Blaise C, Gagné F, Harwood M, Quinn B, Hanana H (2018) Ecotoxicity responses of the freshwater cnidarian Hydra attenuata to 11 rare earth elements. Ecotoxicol Environ Saf 163:486-491

Bradford MM (1976) A rapid and sensitive method for the quantitation of microgram quantities of protein utilizing the principle of protein-dye binding. Anal Biochem 72:248-254

Bustamante P, Miramand P (2005) Subcellular and body distributions of 17 trace elements in the variegated scallop Chlamys varia from the French coast of the Bay of Biscay. STOTEN 337:59-73

Censi P, Randazzo LA, D'Angelo S, Saiano F, Zuddas P, Mazzola S, Cuttitta A (2013) Relationship between lanthanide contents in aquatic turtles and environmental exposures. Chemosphere 91: $1130-1135$

Chen Y, Zhu W, Shu F, Fan Y, Yang N, Wu T, Ji L, Xie W, Bade R, Jiang $\mathrm{S}$, Liu X (2020) Nd2O3 nanoparticles induce toxicity and cardiac/ cerebrovascular abnormality in zebrafish embryos via the apoptosis pathway. Inter J Nanomed 15:387-400

Cui J, Zhang Z, Bai W et al (2012) Effects of rare earth elements La and $\mathrm{Yb}$ on the morphological and functional development of zebrafish embryos. J Environ Sci 24:209-213

Dubé M, Auclair J, Hanana H, Turcotte P, Gagnon C, Gagné F (2019) Gene expression changes and toxicity of selected rare earth elements in rainbow trout juveniles. Comp Biochem Physiol Part - C: Toxicol and Pharmacol 223:88-95

Environmental Protection Series, 1990. Biological test method: acute lethality test using rainbow trout. Method Development and Applications Section, Environmental Technology Centre, Environment Canada (Report EPS 1/RM/9)

Finney D (1964) The spearman-Karber method. Statistical methods in biological assay, 524-530

Fu Y, Li F, Xu T, Cai S, Chu W, Qiu H, Sha S, Cheng G, Xu Q (2014) Bioaccumulation, subcellular, and molecular localization and damage to physiology and ultrastructure in Nymphoides peltata (Gmel.) O. Kuntze exposed to yttrium. Environ Sci Poll Res 21:2935-2942

Fujimoto Y, Sakuma S, Inoue T, Uno E, Fujita T (2002) The endocrine disruptor nonylphenol preferentially blocks cyclooxygenase-1. Life Sci 70:2209-2214

Gagne F (2014) Chap 10: Genotoxicity. Biochemical ecotoxicology: principles and methods. Elsevier Inc, USA

Gagné F, Blaise C (1996) Available intracellular Zn as a potential indicator of heavy metal exposure in rainbow trout hepatocytes. Environ Toxicol and Wat Qual J 11:319-325

Gonzalez V, Vignati DA, Leyval C, Giamberini L (2014) Environmental fate and ecotoxicity of lanthanides: are they a uniform group beyond chemistry? Environ Int 71:148-157

Hanana H, Turcotte P, Pilote M, Auclair J, Gagnon C, Gagné F (2017) Biomarker assessment of lanthanum on a freshwater invertebrate, Dreissena polymorpha. SOJ Biochem 3:1-9

Hanana H, Turcotte P, Dubé M, Gagnon C, Gagné F (2018) Response of the freshwater mussel, Dreissena polymorpha to sub-lethal concentrations of samarium and yttrium after chronic exposure. Ecotoxicol Environ Saf 165:662-670

He M, Wang L, Wu J, Xiao J (2016) $\mathrm{Ln}^{3+}$-mediated self-assembly of a collagen peptide into luminescent banded helical nanoropes. Chemistry 22:1914-1917

Hu X, Wang X-R, Wang C (2006) Bioaccumulation of lanthanum and its effect on growth of maize seedlings in a red loamy soil. Pedosphere 16:799-805

Hu H, Zhao P, Liu J, Ke Q, Zhang C, Guo Y, Ding H (2018) Lanthanum phosphate/chitosan scaffolds enhance cytocompatibility and osteogenic efficiency via the Wnt/ $\beta$-catenin pathway. J Nanobiotechnology 16: 98

Huang P, Li J, Zhang S, Chen C, Han Y, Liu N, Xiao Y, Wang H, Zhang M, Yu Q, Liu Y (2011) Effects of lanthanum, cerium, and neodymium on the nuclei and mitochondria of hepatocytes: accumulation and oxidative damage. Environ Toxicol Pharmacol 31:25-32

Jha AM, Singh AC (1995) Clastogenicity of lanthanides: induction of chromosomal aberration in bone marrow cells of mice in vivo. Mut Res 341:193-197

Kulaksiz S, Bau M (2011) Rare earth elements in the Rhine River, Germany: first case of anthropogenic lanthanum as a dissolved microcontaminant in the hydrosphere. Environ Inter 37:973-979

Liao F, Peng XY, Yang F, Ke QF, Zhu ZH, Guo YP (2019) Gadoliniumdoped mesoporous calcium silicate/chitosan scaffolds enhanced bone regeneration ability. Mater Sci Eng C Mater Biol Appl 104: 109999 
Mayfield DB, Fairbrother A (2015) Examination of rare earth element concentration patterns in freshwater fish tissues. Chemosphere 120: 68-74

Moermond CTA, Tijink J, van Wezel AP, Koelmans AA (2001) Distribution, speciation, and bioavailability of lanthanides in the Rhine-Meuse Estuary, the Netherlands. Environ Toxicol Chem 20: 1916-1926

Olive PL (1988) DNA precipitation assay: a rapid and simple method for detecting DNA damage in mammalian cells. Environ Mol Mutagenesis 11:487-495

Oral R, Bustamante P, Warnau M, d'Ambra A, Guida M, Pagano G (2010) Cytogenetic and developmental toxicity of cerium and lanthanum to sea urchin embryos. Chemosphere 81:194-198

Pagano G, Guida M, Tommasi F, Oral R (2015) Health effects and toxicity mechanisms of rare earth elements - knowledge gaps and research prospects. Ecotoxicol Environ Saf 115:40-48

Rodrigo MAM, Jimemez AMJ, Haddadd Y, Bodoor K, Adam P, Krizkova S, Heger Z, Adam V. 2020. Metallothionein isoforms as double agents - their roles in carcinogenesis, cancer progression and chemoresistance Drug Resist Updat 52: 100691

Roth A (1982) Sensitivity of catfish electroreceptors: dependence on freshwater ions and skin potential. J Comp Physiol - A 147:329-337

Rundle A, Robertson AB, Blay AM, Butler KM, Callaghan NI, Dieni CA, MacCormack TJ (2016) Cerium oxide nanoparticles exhibit minimal cardiac and cytotoxicity in the freshwater fish Catostomus commersonii. Comp Biochem Physiol Part - C: Toxicol and Pharmacol 181-182:19-26

Sage H, Vernon RB, Funk SE, Everitt EA, Angello J (1989) SPARC, a secreted protein associated with cellular proliferation, inhibits cell spreading in vitro and exhibits $\mathrm{Ca}+2$-dependent binding to the extracellular matrix. J Cell Biol 109:341-356
Sun X, He M, Wang L, Luo L, Wang J, Xiao J (2019) Luminescent biofunctional collagen mimetic nanofibers. ACS Omega 4:16270 16279

Tomlinson G, Mutus B, McLennan I, Mooibroek MJ (1982) Activation and inactivation of purified acetylcholinesterase from Electrophorus electricus by lanthanum (III). Biochim Biophys Acta 703:142-148

Tranchida G, Oliveri E, Angelone M, Bellanca A, Censi P, D'Elia M, Neri R, Placenti F, Sprovieri M, Mazzola S (2011) Distribution of rare earth elements in marine sediments from the Strait of Sicily (western Mediterranean Sea): evidence of phosphogypsum waste contamination. Mar Poll Bull 62:182-191

Trifuoggi M, Pagano G, Guida M, Palumbo A, Siciliano A, Gravina M, Lyons DM, Burić P, Levak M, Thomas PJ, Giarra A (2017) Comparative toxicity of seven rare earth elements in sea urchin early life stages. Environ Sci Poll Res 24:20803-20810

Tu Q, Wang X, Tian L, Dai L (1994) Bioaccumulation of the rare earth elements lanthanum, gadolinium and yttrium in carp (Cyprinus carpio). Environ Poll 85:345-350

Velasco G, Cal S, Merlos-Suárez A, Ferrando AA, Alvarez S, Nakano A, Arribas J, López-Otín C (2000) Human MT6-matrix metalloproteinase: identification, progelatinase a activation, and expression in brain tumors. Cancer Res 60:877-882

West DC, Sattar A, Kumar S (1985) A simplified in situ solubilization procedure for the determination of DNA and cell number in tissue cultured mammalian cells. Anal Biochem 147:289-295

Wills ED (1987) Evaluation of lipid peroxidation in lipids and biological membranes. In: Snell K, Mullock B (eds) Biochemical toxicology. A practical Approach. IRL Press, Oxford, pp 127-152

Publisher's note Springer Nature remains neutral with regard to jurisdictional claims in published maps and institutional affiliations. 